\title{
INCREMENTAL ROLE OF PATHOLOGICAL PERSONALITY TRAITS IN THE PREDICTION OF SUICIDAL IDEATION IN GENERAL AND PSYCHIATRIC INPATIENT SAMPLE
}

\author{
Viktorija Perepjolkina $^{1, \#}$, Jeḷena L,ubenko ${ }^{2}$, Jeḷena Koḷesṇikova ${ }^{2}$, \\ Kristīne Mārtinsone ${ }^{2}$, and Ainārs Stepens ${ }^{3}$ \\ ${ }^{1}$ Faculty of Communications, Rīga Stradinš̌ University, 16 Dzirciema Str., Rīga, LV-1007, LATVIA \\ ${ }^{2}$ Faculty of Public Health and Social Welfare, Rīga Stradinš University, 26a Anniṇmuižas Blvd., Rīga, LV-1067, LATVIA \\ ${ }^{3}$ Military Medicine Research and Study Centre, Rīga Stradiṇš University, 23 Kapseḷu Str., Rīga, LV-1046, LATVIA \\ \# Corresponding author, viktorija.perepjolkina@ rsu.Iv
}

Communicated by Modra Murovska

\begin{abstract}
The aim of this study was to evaluate the utility of the pathological personality traits in predicting suicidal ideation, especially in combination with other risk factors, such as the level of depression, prior attempts of suicide, low self-esteem, low level of perceived social support and self-esteemby-social support interaction, both in general and in psychiatric inpatient samples. Data were analysed within two samples: non-clinical general sample $(n=461)$ and psychiatric inpatient sample $(n=131)$. Latvian Clinical Personality Inventory (LCPI) was used as the instrument for data collection. LCPI is a comprehensive multi-scale multi-item inventory, which consists of nine clinical scales (including Depression Symptom Scale), 33 pathological personality scales, five functioning scales, and five additional scales, including a Suicidal Ideation Scale, Low Self-esteem Scale and Lack of Perceived Social Support Scale. Results of the hierarchical regression analysis showed that several facet-level pathological personality traits (depressivity, self-harm, dissociation proneness, submissiveness, and suspiciousness) added significant incremental variance to the prediction of suicidal ideation above and beyond the well-known main risk factors of suicidal ideation, such as depression and prior suicide attempt. This effect remained stable even after taking into account additional interpersonal risk factors, such as low self-esteem, low level of perceived social support and self-esteem-by-perceived social support interaction. The incremental effect of personality traits was medium in the psychiatric inpatient sample and small in the general sample. Findings of the study may assist in early screening for persons with suicide risk and for developing prevention programmes in different settings.
\end{abstract}

Key words: Latvian Clinical Personality Inventory (LCPI), pathological personality traits, risk factors for suicide, suicidal ideation.

\section{INTRODUCTION}

Suicidal ideation (suicidal ideas) in DSM-5 is defined as "thoughts about self-harm, with deliberate consideration or planning of possible techniques of causing one's own death" (Anonymous, 2013, p. 830). Most people who have suicidal thoughts do not go on to make suicide attempts, but it is considered to be a risk factor for death by suicide (Gliatto and Rai, 1999). Suicidal ideation has a straightforward definition - suicidal thoughts — but there are some other related signs and symptoms like feeling helpless and lonely, and low self-esteem. Suicidal ideation is generally associ- ated with depression and other mood disorders, and it seems to have associations with many other mental disorders, life and family events, all of which may increase the risk of suicidal ideation. There are several mental disorders that appear to be comorbid with suicidal ideation or that considerably increase the risk of suicidal ideation (Hemelrijk et al., 2012).

Every year close to 800000 people take their own life and there are many more people who attempt suicide worldwide (Anonymous, 2017). Epidemiological studies have identified a number of demographic, psychosocial, and psychiat- 
ric risk factors for suicide. Every suicide is a tragedy that affects families, communities and entire countries and has a long-lasting effect on the people left behind. Identifying not only the main risk factors, but also potentially latent vulnerability factors that increase the capacity of one's engagement in a suicidal behaviour, would likely increase the precision of predictions that could be made about individuals who may be at death risk by suicide. In addition, knowing such latent factors would be useful in determining targets for preventive efforts and for proper psychological assessment.

One of the underlying factors in suicidal behaviour is the individuals' personality. Identifying personality-based risk factors for suicide attempts and suicidal ideation is an important consideration for research, prevention and clinical care alike. Most prior research has focused on single personality disorders (PD) or categorical PD diagnoses and it has been found that borderline personality disorder (PD) is one of the risk factors for suicidal ideation and suicidal behaviour (Soloff et al., 2000; Anonymous, 2013). Nowadays, due to the recognition of many limitations of the categorical model of personality disorder a substantial shift to a dimensional approach has occurred (Widiger and Simonsen, 2005). For example, in the alternative DSM-5 model for personality disorders (PDs), PDs are characterised by impairments in personality functioning and particular constellations of pathological personality traits. According to DSM-5 Section III (Anonymous, 2013, pp. 766-767), borderline personality disorder is characterised by seven pathological personality traits: emotional lability, anxiousness, separation insecurity, depressivity, impulsivity, risk taking and hostility. In a study based on an expert consensus approach, three more pathological personality traits were assigned as highly relevant for borderline PD: self-harm, aggression, and dissociation proneness (Samuel et al., 2012, pp. 32-33). It can be assumed that pathological personality traits relevant to borderline PD could be predictive for suicidal ideation, but it is necessary to test this hypothesis.

During past decades, different models of pathological or maladaptive personality traits have been developed (Widiger and Simonsen, 2005) and one of them is the model of pathological personality traits recently developed in Latvia and operationalised in the Latvian Clinical Personality Inventory (LCPI) (Perepjolkina et al., in press). In this model, 33 facet-level pathological personality traits are organised into seven broad domains: Oddity, Detachment, Antagonism, Impulsivity, Dependence (or Subordination), Negative Affectivity and Compulsivity, which can be grouped into four higher-order domains: Schizotypy, Dissociality, Neuroticism and Compulsivity. This model includes all facet-level traits relevant to the borderline PD mentioned above, which allows us to test them as potential predictors of suicidal ideation. In this model, facet-level trait rashness corresponds to the facet-level trait impulsivity in the DSM-5 trait model, and trait hostility is represented by two facet-level traits: intemperance and harshness.
The main objective of this study was to evaluate utility of pathological personality traits in predicting suicidal ideation, especially in combination with other well known risk factors, such as severity of symptoms of general depressive disorder and prior attempts of suicide, as well as interpersonal risk factors like feelings of inferior self-worth (low self-esteem), low level of perceived social support, and self-esteem-by-perceived social support interaction, both in a general and psychiatric inpatient sample.

\section{MATERIALS AND METHODS}

The sample for this study was selected from the LCPI development sample by including valid protocols from participants representing the non-clinical general population and inpatients receiving treatment in psychiatric clinics. All participants were required to meet the following criteria: (a) 18 years of age or older, (b) provide consent and ability to complete the study protocol in Latvian. For the psychiatric inpatient sample, additional criteria were: (c) to endorse or exhibit current psychiatric symptoms, and (d) attending physician's admission. The study sample consisted of two subsamples: (1) general sample $(\mathrm{n}=461$, age range from 18 to $79, \mathrm{M}=31.74, \mathrm{SD}=14.85$ years, $24.7 \%$ male; 19 persons had at least one suicide attempt in the past and 88 persons scored above the critical cut-off point on the LCPI Depression Scale (DP scale)), and (2) psychiatric inpatient sample $(\mathrm{n}=131$, age range from 18 to $82, \mathrm{M}=43.55$, $\mathrm{SD}=14.37$ years, $32.8 \%$ male; 26 persons had at least one suicide attempt in the past and 90 persons scored above the critical cut-off point on the LCPI DP scale).

Participants from the psychiatric inpatient sample were recruited from two mental health clinics, located in the capital of Latvia. Patients were contacted individually. After providing informed consent, the anonymous survey packet was completed. From the general sample, data were collected mostly by using an online platform, employing the snowball sampling method, but $27 \%$ of participants (student subsample) were assessed frontally during their personality psychology study course, in which they filled in paper-pencil versions of questionnaires for a course credit. For all participants, anonymity was guaranteed.

All participants filled in a demographic questionnaire indicating background information (age, sex, income level, marital status, education level, occupational status and area of occupation) and a second preliminary item pool $(\mathrm{k}=664)$ of Latvian Clinical Personality Inventory. Items were answered on a 4-point response format: from 0 - 'totally disagree' to 3 - 'totally agree'. For the purpose of this study, final versions of the following LCPI scales were scored: 1) 33 facet-level pathological personality trait scales (Cronbach's alpha for these scales in different samples ranged from 0.76 to 0.96 , with a median of 0.87$)$; 2) Depression Symptom Scale (DP) ( $\mathrm{k}=24$, Cronbach's alpha in different samples ranged from 0.91 to 0.97 ; the DP scale has demonstrated good sensitivity $=0.95$ and specificity $=0.91$ for major depressive disorder) (Perepjolkina et al., 
2017); 3) Suicidal Ideation ( $\left.\mathrm{DPP}^{1}\right)$ Scale ( $\mathrm{k}=6$, Cronbach's alpha ranged from 0.80 to 0.93 ); 4) Low Self-esteem (MI) Scale ( $\mathrm{k}=9$, Cronbach's alpha ranged from 0.80 to 0.93 ); 5) Lack of Perceived Social Support Scale (SA) $(k=4$, Cronbach's alpha ranged from 0.76 to 0.81$)$; 6) the answer on the LCPI item: "I have tried to attempt a suicide" was used as an indicator of the past suicide attempt. Original responses to this item, made on a 4-point response format, for the purposes of this study were recoded into dichotomised scoring format: answers ' 0 '- 'totally disagree' and ' 1 ' 'partly disagree' were coded as ' 0 ', and answers: '2' 'partly agree' and ' 3 ' - 'totally agree' - were coded as ' 1 '.

All procedures were approved by the Ethical Board of Rīga Stradiňš University.

SPSS software v.20.0 was used for processing and analysis of the data. The main statistical methods applied were Pearson product-moment correlation coefficient, followed by simple, stepwise and hierarchical linear regression analysis. As results remained unchanged when controlling for age and gender; results are reported without these variables entered as covariates. $R^{2}$ change effect sizes were interpreted by Cohen (1988) conventions (change effects of 0.01, 0.06, and 0.14 were interpreted as small, medium, and large, respectively).

\section{RESULTS}

Associations between suicidal ideation, risk factors for suicide (level of depression, past suicide attempt, perceived social support, self-esteem), age, gender and pathological personality traits. First it was necessary to test associations between suicidal ideation and the four main risk factors of suicide, as well as with demographic variables. Pearson product-moment correlations were computed $^{2}$. It was found that neither age nor gender were statistically significantly correlated with suicidal ideation or depression symptom severity in the general sample, but in the psychiatric inpatient sample the only significant weak correlation was found between DP scale and gender (being female was associated with higher scores on the DP scale, $r=0.25, p<0.01)$. Depression symptom severity was positively moderately correlated with both suicidal ideation and having attempted suicide in the past in both samples. Lack of perceived social support and low self-esteem in both samples were positively moderately correlated with current suicidal ideation ( $r$ ranged from 0.32 to 0.52 for Lack of Social Support and from 0.49 to $0.56, p<0.001$, for Low Self-esteem) and with severity of depression symptoms (DP scale score) ( $r$ ranged from 0.45 to 0.49 for Lack of Social Support and from 0.76 to $0.81, p<0.001$, for Low Self-esteem).

\footnotetext{
${ }^{1}$ Original abriviations of the LCPI scales corresponding to its labels in Latvian are mentioned.

2 The table with correlation coefficients between the LCPI facet-level pathological personality traits and demographic variables, LCPI DP, MI, SA and DPP scale scores is available upon request.
}

In the next stage of data analysis, associations between suicidal ideation and pathological personality traits were analysed. The analysis was performed for each sample separately. Based on the obtained zero-order correlations, traits that showed at least weak statistically significant correlations $(r \geq 0.20 \mid, p \leq 0.05)$ with suicide ideation were retained for the future analysis (21 facet-level trait scales for the general sample, 22 - for the psychiatric inpatient sample). Traits that did not correlate with the suicidal ideation in both samples were mainly from the Compulsivity and Antagonism domain with only some exceptions.

Which pathological personality traits are predictive of suicidal ideation? Since a significant number of personality traits were found to be associated with suicidal ideation, and because of a relatively small sample size, at least in the clinical sample, in the next stage of data analysis a series of stepwise linear regression analyses with Suicidal Ideation as a dependent variable was conducted to reduce the number of traits to be used in further regression analysis. In the interest of space, these results were not included in detail, but they are available upon request. It was found that five facets, namely, Irresponsibility, Depressivity, Submissiveness, Self-harm and Social withdrawal were predictive for suicidal ideation in both samples. Some other facets were found to be significant predictors of suicidal ideation only in one of the studied samples. For example, in general sample 11 facets in total survived in this stage of data analysis, and in addition to the five facets mentioned above, traits such as Harshness, Aggression, Indecisiveness, Dissociation proneness, Restricted affectivity and Close relationship avoidance were predictive for suicidal ideation when analysed in the framework of the particular domain. In the psychiatric inpatient sample, in addition to five 'common' traits, four other traits (Harshness, Emotional lability, Impersistence and Suspiciousness) where found to be predictive for suicidal ideation in this stage of data analysis.

Which pathological personality traits predict severity of current suicidal ideation best of all? Are these traits identical in the general and psychiatric inpatient samples? In the next stage of analysis, a stepwise regression analysis was conducted for each sample, with Suicidal ideation as a dependent variable to be predicted by the facetlevel scales identified in the second stage of analysis (11 facets for the general sample, 9 facets — for the psychiatric inpatient sample). Obtained results are summarised in Table 1. In both samples, this time, only three to four traits were found to be significant predictors of the current suicidal ideation. $R^{2}$ values in the final step ranged from $37.0 \%$ in the general sample to $60.6 \%$ in the psychiatric inpatient sample. In both samples, Depressivity was entered in the first step and Self-harm was entered in the second step. The traits that were entered after the third step differed between these samples (see Table 1). For example, in the general sample, Submissiveness was entered in the third step and Dissociation proneness was entered in the final step of regression. In the psychiatric inpatient sample, Suspiciousness was entered in the third step and Impersistence was entered in the fourth step (see Table 1). 
RESULTS OF STEPWISE LINEAR REGRESSION ANALYSIS FOR FACET-LEVEL PERSONALITY TRAITS, PREDICTING SUICIDAL IDEATION IN COMMUNITY AND PSYCHIATRIC INPATIENT SAMPLES

\begin{tabular}{|c|c|c|c|}
\hline \multicolumn{2}{|l|}{ Community sample } & \multicolumn{2}{|c|}{ Psychiatric inpatient sample } \\
\hline \multicolumn{2}{|c|}{ Step $1\left(\Delta R^{2}=36.3 \%, \Delta F=274.89 * * *\right)$} & \multicolumn{2}{|c|}{ Step $1\left(\Delta R^{2}=44.3 \%, \Delta F=102.43 * * *\right)$} \\
\hline Depressivity & $\beta=0.60 * * *$ & Depressivity & $\beta=0.67 * * *$ \\
\hline \multicolumn{2}{|c|}{ Step $2\left(\Delta R^{2}=9.8 \%, \Delta F=87.06^{* * * *}\right)$} & \multicolumn{2}{|c|}{ Step $2\left(\Delta R^{2}=11.9 \%, \Delta F=34.82^{* * *}\right)$} \\
\hline Depressivity & $\beta=0.44 * * *$ & Depressivity & $\beta=0.52^{* * *}$ \\
\hline Self-harm & $\beta=0.35^{* * *}$ & Self-harm & $\beta=0.38^{* * *}$ \\
\hline Depressivity & $\beta=0.48^{* * *}$ & Depressivity & $\beta=0.47 * * *$ \\
\hline Self-harm & $\beta=0.36^{* * *}$ & Self-harm & $\beta=0.33 * * *$ \\
\hline Submissiveness & $\beta=-0.09 *$ & Suspiciousness & $\beta=0.18^{* *}$ \\
\hline \multicolumn{2}{|c|}{ Step $4\left(\Delta R^{2}=0.6 \%, \Delta F=5.35^{* * *}\right)$} & \multicolumn{2}{|c|}{ Step $4\left(\Delta R^{2}=1.9 \%, \Delta F=6.04^{*}\right)$} \\
\hline Depressivity & $\beta=0.46^{* * *}$ & Depressivity & $\beta=0.58 * * *$ \\
\hline Submissiveness & $\beta=-0.11^{* *}$ & Suspiciousness & $\beta=0.20^{* *}$ \\
\hline Dissociation proneness & $\beta=0.09^{*}$ & Impersistence & $\beta=-0.18 *$ \\
\hline \multicolumn{2}{|c|}{ Total model: $R^{2}=47.0 \%$, Adj. $R^{2}=46.8 \%, F(4,480)=107.28 * * *$} & \multicolumn{2}{|c|}{ Total model: $R^{2}=60.6 \%$, Adj. $R^{2}=59.4 \%, F(4,126)=48.53 * * *$} \\
\hline
\end{tabular}

How much does each risk factor (level of depression, past suicide attempt, (lack of) perceived social support, (low) self-esteem, perceived social support-by-selfesteem interaction, and personality traits) account for the level of suicidal ideation alone? Next, a series of simple linear regressions were used to determine effect of each risk factor on the level of suicidal ideation alone. It was found that the level of depression (severity of depression symptoms), when used alone, performed almost equally in both samples and accounted for $34.7 \%$ (in general sample) and for $30.5 \%$ (in clinical sample) of variance in suicidal ideation, approving generality of this common factor. Past suicide attempt accounted for $11.1 \%$ of suicidal ideation in the general sample and for $27.9 \%$ in the psychiatric sample. Low self-esteem accounted for $23.8 \%$ in the general sample and $31.7 \%$ in clinical sample. Lack of the perceived social support, accounted for $10.1 \%$ in the general sample and $26.9 \%$ in the psychiatric sample, but low self-esteem-byperceived social support interaction, when used alone, accounted for more than $20 \%$ in current suicidal ideation in both samples $\left(R^{2}\right.$ ranging from $20.7 \%$ in the general sample to $35.1 \%$ in the psychiatric sample). Finally, it was found that the set of personality traits, selected for each sample in the previous stage of analysis (see Table 1), when used alone (entered simultaneously as a set of predictor variables) independently from other risk factors, accounted for $47.2 \%$ in the general sample and for $60.6 \%$ in the psychiatric sample.

Are pathological personality traits able to account for the level of suicidal ideation after controlling for other risk factors? In the final step of analysis, to determine incremental effect of pathological personality traits in predicting suicidal ideation after controlling for other risk factors, hierarchical linear regression (using Enter method) was used. Suicidal ideation score was included as the dependent variable to be predicted by score of the Depression scale of LCPI in Model 1, prior attempt/-s of suicide in Model 2, score of Low Self-esteem Scale in Model 3, score of the Lack of Perceived Social Support in Model 4, self-esteemby-perceived social support interaction in Model 5 and personality traits (which were identified in the previous stage of analysis (see Table 1) as the predictors for suicidal ideation in the last step of hierarchical regression model. Obtained results are presented in Table 2. Results revealed that personality traits significantly improved prediction of suicidal ideation in both samples. In the general sample, the $R^{2}$ change $8.4 \%, \Delta F(4,475)=20.43, p<0.001$, and in the psychiatric inpatient sample, the $R^{2}$ change was $12.11 \%$, $\Delta F(4,121)=10.26, p<0.001$ (see Table 2). This incremental effect of personality traits was not only significant, but also medium in its change effects. It is worth mentioning that in the psychiatric sample each trait entered in the last model accounted for significant variance in suicidal ideation alone as well (Depressivity, $B=2.667, S E=0.695$, $\beta=0.509, p<0.001$; Self-harm, $B=1.358, S E=0.443$, $\beta=0.228, p<0.01$; Suspiciousness, $B=1.094, S E=0.361$, $\beta=0.190, p<0.01$ and Impersistence, $B=-0.946$, $S E=0.432, \beta=-0.178, p=0.03)$. In the general sample, three of four entered personality traits accounted for significant variance after controlling all other risk factors (Depressivity, $B=1.078, S E=0.232, \beta=0.256, p<0.001$; Selfharm, $B=1.468, S E=0.235, \beta=0.250, p<0.01$; Submissiveness, $B=-0.505, S E=0.160, \beta=-0.129, p<$ 0.01 and Dissociation proneness, $B=0.258, S E=0.169$, $\beta=-0.129, p=0.127$ ).

\section{DISCUSSION}

The obtained results showed that facet-level personality traits added significant incremental variance to the predic- 
RESULTS OF HIERARCHICAL LINEAR REGRESSION ANALYSIS, PREDICTING SUICIDAL IDEATION IN COMMUNITY AND PSYCHIATRIC INPATIENT SAMPLES

\begin{tabular}{|c|c|}
\hline Community sample & Psychiatric inpatient sample \\
\hline Model $1\left(\Delta R^{2}=34.8 \%, \Delta F=257.47^{* * *}\right)$ & Model $1\left(\Delta R^{2}=30.5 \%, \Delta F=56.66^{* * *}\right)$ \\
\hline Severity of depression & Severity of depression \\
\hline Model $2\left(\Delta R^{2}=5.5 \%, \Delta F=44.19^{* * *}\right)$ & Model $2\left(\Delta R^{2}=16.8 \%, \Delta F=40.86^{* * *}\right)$ \\
\hline Past suicide attempts & Past suicide attempts \\
\hline Model $3\left(\Delta R^{2}=0.03 \%, \Delta F=2.40\right.$ n.s. $)$ & Model $3\left(\Delta R^{2}=0.1 \%, \Delta F=2.37\right.$ n.s. $)$ \\
\hline Low Self-esteem & Low Self-esteem \\
\hline Model $4\left(\Delta R^{2}=0.02 \%, \Delta F=1.43\right.$ n.s. $)$ & Model $4\left(\Delta R^{2}=3.2 \%, \Delta F=8.43 * *\right)$ \\
\hline Lack of Perceived Social Support $\quad \beta=0.05$ n.s. & Lack of Perceived Social Support \\
\hline Model $5\left(\Delta R^{2}=2.3 \%, \Delta F=19.20 * * *\right)$ & Model $5\left(\Delta R^{2}=0.06 \%, \Delta F=1.55\right.$ n.s. $)$ \\
\hline $\begin{array}{l}\text { Low self-esteem x Lack of Perceived } \beta=0.77 * * * \\
\text { Social Support }\end{array}$ & $\begin{array}{l}\text { Low Self-esteem x Lack of Perceived } \beta=0.25 \text { n.s. } \\
\text { Social Support }\end{array}$ \\
\hline Model $6\left(\Delta R^{2}=8,4 \%, \Delta F=20.43 * * *\right)$ & Model $6\left(\Delta R^{2}=12.11 \%, \Delta F=10.26^{* * *}\right)$ \\
\hline Personality traits $^{\mathrm{a}} \quad \beta^{\mathrm{a}}$ from 0.07 to 0.23 & Personality traits $^{\mathrm{c}} \quad \beta^{\mathrm{b}}$ from 0.18 to 0.51 \\
\hline Total model: $R^{2}=51.4 \%$, Adj. $R^{2}=50.5 \%, F(9,475)=55.76^{* * *}$ & Total model: $R^{2}=64.3 \%$, Adj. $R^{2}=61.6 \%, F(9,120)=24.16^{* * *}$ \\
\hline
\end{tabular}

\footnotetext{
${ }^{\mathrm{a}}$ Entered personality traits were: Depressivity $(\beta=0.26, p<0.001)$, Self-harm $(\beta=0.25, p<0.001)$, Submissiveness $(\beta=-0.13, p<0.01)$, and Dissociation pronesess $(\beta=0.13, p>0.05)$.

${ }^{\mathrm{b}}$ Entered personality traits were: Depressivity $(\beta=0.51, p<0.001)$, Self-harm $(\beta=0.23, p<0.01)$, Suspiciousness $(\beta=0.19, p<0.01)$, and Impersistence $(\beta=-0.18, p<0.05)$.
}

tion of suicidal ideation above and beyond the well-known main risk factors of suicidal ideation, such as depression and prior suicide attempt, and this effect remained stable even after taking into account additional interpersonal risk factors like low self-esteem, low level of perceived social support and self-esteem-by-perceived social support interaction. This incremental effect of personality traits was medium in the psychiatric inpatient sample and small in the general sample. Fluid vulnerability theory (Rudd, 2006) posits that acute suicidal episodes increase in severity when trait-based and state-based risk factors interact, especially among individuals who have been previously suicidal. The results of our study approve this proposition.

It was found that in both samples, depressivity and selfharm persistently incrementally predicted severity of current suicidal ideation above and beyond the common risk factors for suicide attempt and suicidal ideation. These findings are in line with our assumption, that at least some borderline personality disorder traits could be predictive for suicidal ideation. In the LCPI trait model, depressivity is defined as the tendency or disposition towards feelings of being down, miserable, and/or hopeless, difficulty in recovering from such moods; pessimism about the future; lack of enjoyment from, or engagement in life's experiences; deficits in the capacity to feel pleasure and take interest in things (Perepjolkina et al., in press). That means that scores from the LCPI Depressivity Scale can be used as a proxy measure of trait-hopelessness - a trait, which has gathered extensive empirical evidence as a highly reliable risk factor for understanding suicidal thoughts and behaviours (e.g., Beck et al., 1990), which is considered to be vital for the as- sessment and management of suicidal individuals (Bryan and Rudd, 2006). The Self-harm Scale in the LCPI can be used as a proxy measure for non-suicidal self-injury — another well-known powerful risk factor for suicidal ideation and suicide attempt (see Nock et al., 2006).

One more trait typical for borderline PD - dissociation proneness - was found to be predictive for suicidal ideation, but only in the general sample. In this sample, one more trait — submissiveness - was predictive for suicidal ideation. Submissiveness is closely related to borderline personality features likes anxiousness, low self-esteem and separation insecurity, but it is interesting that just submissiveness, not other related traits, turned out to be significant predictor of suicidal ideation in the general sample.

In the psychiatric inpatient sample, there was one more trait - suspiciousness, which was found to be a powerful predictor of suicidal ideation, even after taking into account other predictor variables. One can expect that higher rates of suspiciousness may be related to the difficulty in seeking help, so the more suspicious an individual is, the less likely he or she will consult or reach for help from others in a crisis situation.

In general, the results of this study are in line both with interpersonal-psychological theory of suicidal behaviour (Joiner Jr, 2005; Ribeiro and Joiner, 2009) and fluid vulnerability theory (Rudd, 2006). Nonetheless, our findings present some interesting insights on the impact of pathological personality traits and about the relative importance of various well-known risk factors of suicidal ideation when ana- 
lysed together in one model. We had a possibility to analyse the stability of obtained findings by comparing acquired results in two different samples and to show common and specific tendencies of relative importance of each analysed risk factor for prediction of suicidal ideation.

Our findings approve that well documented risk factors, such as the level of depression, past suicide attempts, low level of perceived social support (a proxy for thwarted belongingness) and feelings of inferior self-worth (a proxy for burdensomeness), independently significantly increase the risk and severity of suicidal ideation, accounting for at least $10 \%$ to $35 \%$ in variance of suicidal ideation. The level of depression was found to be one of the most powerful predictors of suicidal ideation. This finding is in line with many other studies (e.g., Rudd et al., 2011) and approves that this factor is common and not specific to any particular population.

In the current study past suicide attempt was shown to be the next most important factor for prediction of suicidal ideation, especially in the psychiatric inpatient sample. This finding is in line with other studies (Brown et al., 2000) and supports the proposition made in the framework of the interpersonal-psychological theory of suicidal behaviour (Joiner Jr., 2005; Ribeiro and Joiner, 2009) that the most direct and potent means of acquiring the capability for suicide is by having attempted suicide in the past.

Feelings of inferior self-worth (score of the Low Selfesteem Scale) in both samples was found to be an important risk factor for suicidal ideation, accounting for $23.8 \%$ in the general sample and $31.7 \%$ in the psychiatric sample, alone. These results are in line with the proposition of interpersonal-psychological theory of suicidal behaviour that perceived burdensomeness is one of two causal risk factors for suicidal desire (Ribeiro and Joiner, 2009) and also with the assumption of fluid vulnerability theory (Rudd, 2006) that individuals who have chronic, negative shame-based selfschemas (i.e. feeling bad about who one is), which are core to their sense of identity, are innately at increased risk for suicide. Significant positive relationship between suicidal ideation and feelings of inferior self-worth (perceived burdensomeness and trait-like shame) has been found in a variety of studies and samples (e.g., Harris et al., 1997; Joiner et al., 2002; Van Orden et al., 2006). Vice versa, given that shame consists of the global punitive judgment of the self, it seems reasonable that the global positive appraisals of the self, such as pride or positive self-esteem, might counteract or buffer the effects of shame. Clinically these results suggest psychological treatments that explicitly foster positive self-judgments might be effective for reducing suicide risk. From a public health perspective, the results suggest that suicide prevention efforts that foster positive self-regard, in addition to mitigating risk factors for suicide, might yield better outcomes. However, prospective trials are required to test this hypothesised mechanism of change within treatments for suicide risk and suicide prevention programmes.
The next factor found to be negatively predictive for suicidal ideation, when analysed independently from other risk factors, was the lack of the perceived social support. This factor was used as a proxy measure for thwarted belongingness - the second interpersonal aspect supposed by interpersonal-psychological theory to be related to developing the desire for suicide (Ribeiro and Joiner, 2009).

Partially we approved the proposition made in the frame of interpersonal-psychological theory that the interaction of low self-esteem and feelings, where no one is capable to give a helping hand, is particularly pernicious, assuming that the risk for developing the desire for suicide is the greatest when both states are experienced concurrently. Our results suggest that this is true only in the general sample. When depression and past suicide attempts are taken into account, only interaction between self-esteem and perceived social support turned out to be significant, but each of these aspects separately failed to add any significant improvement in the prediction of current suicidal ideation. In the psychiatric sample, after controlling for the main predictor, only perceived social support was a significant independent predictor of suicidal ideation.

Furthermore, there were no demographic predictors of suicide ideation within both samples. This finding is not surprising giving the inconsistencies and null findings in the literature on demographic factors such as gender (Rudd at al., 1996; Miranda et al., 2009), and age (e.g., Rudd at al., 1996).

Several limitations of the present study should be noted. Although the samples were sufficiently large to test the planned hypotheses, additional studies with larger clinical sample are required to determine the generality of observed results. Another sample-based limitation of this study was uneven distribution of gender in the compared samples. While correlation analysis revealed that gender was not associated with the intensity of current suicidal ideation, in future studies it would be necessary to form more equal samples by gender.

Next, it is necessary to stress that our conclusions are limited to current suicidal ideation only. Future studies are needed to determine the role of the pathological personality traits, such as the risk factors for future suicide attempts and death by suicide. Another direction of future studies may be focused on finding not only risk factors for current suicidal ideation and suicidal behaviours, but also on finding possible factors that might protect against suicide risk.

Despite these limitations, the current study provides some useful information about contribution of enduring personality-based dispositions in improving identification of individuals who may be at risk for death by suicide and knowing the latent personality-based factors that are useful in determining targets for preventive efforts and for proper psychological assessment. The results suggest that some individuals indeed may be long-term vulnerable to suicidal ideation and to suicide risk, due to their personality-based 
enduring and stable characteristics, even during periods of relative calm and stability.

It is widely assumed that early detection and treatment are the best ways to prevent suicidal ideation and suicide attempts (Bryan and Rudd, 2000). The findings of this study may assist in early screening for persons at risk of suicide and planning prevention programmes in different settings.

\section{CONCLUSIONS}

The results of this study showed that some traits of abnormal personality were stable predictors of suicidal ideation, both in the clinical and general samples. In both samples, the two traits, depressivity and self-harm (a tendency for non-suicidal self-injury), persistently incrementally predicted severity of current suicidal ideation above and beyond the common risk factors for suicide attempt and suicidal ideation.

In general sample two more traits (dissociation proneness and submissiveness) were found to be predictive of suicidal ideation. In the psychiatric inpatient sample there were two other traits, suspiciousness and impersistence, which were found to be powerful predictors of suicidal ideation, even after taking into account other predictor variables. Taking into account such personality factors, it is possible to increase the specificity of predictions about individuals at risk for suicidal ideation and potentially for death by suicide. Knowing such latent personality-based factors would be useful in determining targets for preventive efforts and for proper psychological assessment.

We can also conclude that LCPI can be used as psychometrically and theoretically sound measures for evaluating the presence and the severity of actual and potential symptoms and signs of the main risk factors for death by suicide. It could be used along with clinical interviews as a part of psychological assessment in a wide variety of settings.

\section{ACKNOWLEDGEMENTS}

The study was supported by Grants No. 5.8 .2 of the National Research Programme of Latvia (Biomedicine, 2014-2017) and Nr. 48-23/2017/0452. 2017-2020, project "The Development of Digitalized Personality Assessment System".

\section{REFERENCES}

Anonymous (2013). Diagnostic and Statistical Manual of Mental Disorders. 5rd edition. American Psychiatric Association. 991 pp.

Anonymous (2017). Suicide. World Health Organization. Available from: http://www.who.int/mediacentre/factsheets/fs398/en/ (accessed 12.05.2019).

Beck, A. T., Brown, G., Berchick, R. J., Stewart, B. L., Steer, R. A. (1990). Relationship between hopelessness and ultimate suicide: A replication with psychiatric outpatients. Amer. J. Psychiatry, 147 (2), 190-195.
Brown, G. K., Beck, A. T., Steer, R. A., Grisham, J. R. (2000). Risk factors for suicide in psychiatric outpatients: A 20-year prospective study. J. Consult. Clin. Psychol., 68 (3), 371-377.

Bryan, C. J., Rudd, M. D. (2000). Advances in the assessment of suicide risk. J. Clin. Psychol., 62, 185-200.

Cohen, J. (1988). Statistical Power Analysis for the Behavioural Sciences. $2^{\text {nd }}$ ed. Lawrence Erlbaum Associates, New York, NY. 579 pp.

Gliatto M. F., Rai A. K. (1999). Evaluation and treatment of patients with suicidal ideation. Amer. Family Phys., 59 (6), 1500-1506.

Harris, E. C., Barraclough, B. (1997). Suicide as an outcome for mental disorders. A meta-analysis. Brit. J. Psychiatry, 170 (3), 205-228.

Hemelrijk, E.,Van Ballegooijen, W., Donker, T., Van Straten, A., Kerkhof, A. (2012). Internet-based screening for suicidal ideation in common mental disorders. Crisis J. Crisis Intervent. Suicide Prev., 33 (4), 215-221.

Joiner Jr., T. E. (2005). Why People Die by Suicide. Harvard University Press.Cambridge, MA. 288 pp.

Joiner Jr. T. E., Pettit, J. W., Walker, R. L., Voelz, Z. R., Cruz, J., Rudd, M. D., Lester, D. (2002). Perceived burdensomeness and suicidality: Two studies on the suicide notes of those attempting and those completing suicide. J. Soc. Clin. Psychol., 21 (5), 531-545.

Miranda, R., Scott, M., Hicks, R., Wilcox, H. C., Harris Munfakh, J. L., Shaffer, D. (2008). Suicide attempt characteristics, diagnoses, and future attempts: Comparing multiple attempters to single attempters and ideators. J. Amer. Acad. Child Adolescent Psychiatry, 47 (1), 32-40.

Nock, M. K., Joiner, T. J., Gordon, K. H., Lloyd-Richardson, E., Prinstein, M. J. (2006). Non-suicidal self-injury among adolescents: Diagnostic correlates and relation to suicide attempts. Psychiatry Res., 144 (1), 65-72.

Perepjolkina, V., Koḷesnikova, J., Mārtinsone, K., Stepens, A. (in press) Latvijas Klīniskais personības tests (LKPT). Tehniskā rokasgrāma. [Latvian Clinical Personality Inventory (LCPI). Technical Manual]. Rīga Stradin̄š University, Rīga (in Latvian)

Perepjolkina, V., Kolesnikova, J., Mārtinsone, K., Stepens, A., Rancans, E. (2017). Criterion-based validity of the Depression scale of Latvian clinical personality inventory. In: Society. Integration. Education. Proceedings of the International Scientific Conference. Volume I. Rēzeknes Tehnolog̣iju akadēmija, RA izdevniecība, Rēzekne, pp. 603-616.

Ribeiro, J. D., Joiner, T. E. (2009). The interpersonal-psychological theory of suicidal behavior: Current status and future directions. J. Clin. Psychol., 65 (12), 1291-1299

Rudd, M. D. (2006). Fluid vulnerability theory: A cognitive approach to under-standing the process of acute and chronic suicide risk. In: Ellis, T. E. (Ed.). Cognition and Suicide: Theory, Research, and Therapy. American Psychological Association, Washington, DC. 409 pp.

Rudd, M. D., Goulding, J, Bryan, C. J. (2011). Student veterans: A national survey exploring psychological symptoms and suicide risk. Prof. Psychol. Res. Practice, 42 (5), 354-360.

Rudd, M. D., Joiner, T., Rajab, M. H. (1996). Relationships among suicide ideators, attempters, and multiple attempters in a young-adult sample. $J$. Abnormal Psychol., 105 (4), 541-550.

Samuel, D. B., Lynam, D. R., Widiger, T. A., Ball, S. A. (2012). An expert consensus approach to relating the proposed DSM-5 types and traits. Personality Disord., 3 (1), 1-16.

Soloff, P. H., Lynch, K. G., Kelly, T. M., Malone, K. M., Mann, J. J. (2000) Characteristics of suicide attempts of patients with major depressive episode and borderline personality disorder: A comparative study. Amer. J. Psychiatry, 157 (4), 601-608.

Van Orden, K. A., Lynam, M. E., Hollar, D., Joiner Jr. T. E. (2006). Perceived burdensomeness as an indicator of suicidal symptoms. Cogn. Ther. Res., 30 (4), 457-467. 
Wenzel, A., Brown, G. K., Beck, A. T. (2009). Cognitive Therapy for Suicidal Patients: Scientific and Clinical Applications. American Psychological Association, Washington, DC. 377 pp.
Widiger, T. A., Simonsen, E. (2005). Alternative dimensional models of personality disorder: Finding a common ground. J. Personality Disord., 19 (2), 110-130.

Received 7 November 2018

Accepted in the final form 7 May 2019

\section{PATOLOGISKO PERSONĪBAS IEZĪMJU PIENESUMS, PROGNOZĒJOT DOMU PAR PAŠNĀVĪBU IZTEIKTĪBAS PAKĀPI VISPĀRĒJĀS POPULĀCIJAS UN PSIHIATRISKO PACIENTU IZLASĒ}

Pētījuma mērḳis bija novērtēt, cik lielu pienesumu dod patoloǵiskās personības iezīmes, prognozējot domu par pašnāvību izteiktības pakāpi vispārējās populācijas un psihiatrisko pacientu izlasē, īpaši gadījumā, kad tiek kontrolēti tādi pašnāvības riska faktori kā depresijas simptomu izteiktība, iepriekšējie pašnāvības mēgeinājumi, zems pašvērtējums, uztvertā sociāla atbalsta trūkuma izjūta un zema pašvērtējuma un uztverta sociāla atbalsta trūkuma izjūtas mijiedarbības efekts. Pētījuma izlasi veidoja divas grupas: neklīniskā vispārējās populācijas izlase ( $\mathrm{n}=461$, respondenti vecumā no $18 \mathrm{līdz} 79$ gadiem, $\mathrm{M}=31,74$, SD = 14,85 gadi; 24,7\% vīrieši) un psihiatrisko pacientu grupa ( $\mathrm{n}=131$, respondenti vecumā no 18 līdz 82 gadiem, $\mathrm{M}=43,55, \mathrm{SD}=14,37$ gadi; 32,8\% vīrieši). Datu iegūšanai tika izmantots Latvijas klīniskais personības tests (LKPT), ar kura palīdzību tika novērtēti visi pētījumā izmantotie pamatmainīgie. No 69 LKPT skalām šajā pētījumā tika analizētas tikai 33 patoloğiskās personības iezīmju skalas, skala: "Depresijas simptomi”, "Domas par pašnāvību", "Mazvērtības izjūta", "Sociālā atbalsta trūkuma izjūta" un kontroles jautājumi par pašnāvības mēǵinājumu/-iem pagātnē. Atbildes tika sniegtas 4-punktu Likerta-tipa skalā $(0=$ nepiekrītu; $1=$ drīzāk nepiekrītu, 2 = gandrīz piekrītu, 3 = piekrìtu). Hierarhiskās regresijas analīzes rezultāti uzrādīja, ka tādas patoloğiskās personības iezīmes kā depresivitāte, nosliece uz tīšu paškaitējumu (plus vēl divas personības iezīmes, kurās bija atškirības katrā no izpētes grupām) deva būtisku ieguldījumu domu par pašnāvību prognozei, izskaidrojot unikālu dispersijas daḷ (12,11\% - vidējs efekta lielums) klīniskajā grupā un (8,4\% - zems efekta lielums) vispārējās populācijas izlasē, pat pēc "klasisko" pašnāvības riska faktoru (depresijas simptomu izteiktība, iepriekšējie pašnāvības mēǵinājumi, zems pašvērtējums, uztvertā sociāla atbalsta trūkuma izjūta un zema pašvērtējuma un uztverta sociāla atbalsta trūkuma izjūtas mijiedarbības efekts) kontroles. Papildus minētajām personības iezīmēm, kuras bija kopīgas abās grupās, tika konstatēts, ka paklaujamība un nosliece uz disociāciju ir vēl divas iezīmes, kuras uzlabo domu par pašnāvību prognozi vispārējās populācijas izlasē, bet aizdomīgums un neatlaidības trūkums, ir iezīmes, kuras dod statistiski nozīmīgu pienesumu domu par pašnāvību prognozes precizitātei psihiatrisko pacientu grupā. "Klasiskie" pašnāvības riska faktori, kombinācijā ar minētajām personības iezīmēm klīniskajā grupā, izskaidroja 64,3\% no domu par pašnāvību skalas rādītāju dispersijas, un 51,4\% - vispārējās populācijas izlasē. Pētījuma rezultāti apliecina, ka personības iezīmēm ir pietiekami svarīga nozīme domu par pašnāvību, un līdz ar to arī, potenciāli, pašnāvības riska prognozēe, un tām būtu vērts pievērst uzmanību, veicot pašnāvības riska novērtējumu. 